\title{
ERRATUM
}

\section{A large-scale RNAi screen identifies LCMR1 as a critical regulator of Tspan8-mediated melanoma invasion}

G Agaësse, L Barbollat-Boutrand, E Sulpice, R Bhajun, M El Kharbili, O Berthier-Vergnes, F Degoul, A de la Fouchardière, E Berger, T Voeltzel, J Lamartine, X Gidrol and I Masse

Oncogene (2017) 36, 5084; doi:10.1038/onc.2017.195; published online 19 June 2017

Correction to: Oncogene (2017) 36, 446-457; doi:10.1038/onc. 2016.219; published online 4 July 2016

The author name in the above paper was published incorrectly.
Correct author name should be M El Kharbili.

The publishers wish to apologize for any inconvenience caused. 